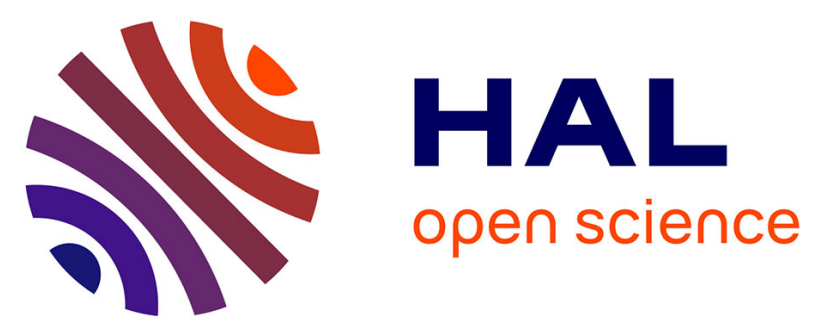

\title{
Assessment of Antibiogram of Multidrug-Resistant Isolates of Enterobacter aerogenes after Biofield Energy Treatment
}

Mahendra Kumar Trivedi, Alice Branton, Dahryn Trivedi, Harish Shettigar, Gopal Nayak, Mayank Gangwar, Snehasis Jana

\section{To cite this version:}

Mahendra Kumar Trivedi, Alice Branton, Dahryn Trivedi, Harish Shettigar, Gopal Nayak, et al.. Assessment of Antibiogram of Multidrug-Resistant Isolates of Enterobacter aerogenes after Biofield Energy Treatment. Pharmaceutical Care \& Health Systems, 2015, 2 (5). hal-01433791

\section{HAL Id: hal-01433791 https://hal.science/hal-01433791}

Submitted on 13 Jan 2017

HAL is a multi-disciplinary open access archive for the deposit and dissemination of scientific research documents, whether they are published or not. The documents may come from teaching and research institutions in France or abroad, or from public or private research centers.
L'archive ouverte pluridisciplinaire HAL, est destinée au dépôt et à la diffusion de documents scientifiques de niveau recherche, publiés ou non, émanant des établissements d'enseignement et de recherche français ou étrangers, des laboratoires publics ou privés.

\section{(c)(1)}

Distributed under a Creative Commons Attribution| 4.0 International License 


\title{
Pharmaceutical Care \& Health Systems
}

\section{Assessment of Antibiogram of Multidrug-Resistant Isolates of Enterobacter aerogenes after Biofield Energy Treatment \\ Mahendra Kumar Trivedi', Alice Branton'1, Dahryn Trivedi', Harish Shettigar', Gopal Nayak', Mayank Gangwar ${ }^{2}$ and Snehasis Jana ${ }^{2 *}$}

${ }^{1}$ Trivedi Global Inc., 10624 S Eastern Avenue Suite A-969, Henderson, NV 89052, USA

${ }^{2}$ Trivedi Science Research Laboratory Pvt. Ltd., Hall-A, Chinar Mega Mall, Chinar Fortune City, Hoshangabad Rd., Bhopal- 462026, Madhya Pradesh, India

\begin{abstract}
Enterobacter aerogenes (E. aerogenes) has been reported as the versatile opportunistic pathogen associated with the hospital infections worldwide. The aim of the study was to determine the impact of Mr. Trivedi's biofield energy treatment on multidrug resistant clinical lab isolates (LSs) of $E$. aerogenes. The MDR isolates of $E$. aerogenes (i.e., LS 45 and LS 54) were divided into two groups, i.e., control and treated. Samples were analyzed for antimicrobial susceptibility pattern, minimum inhibitory concentration (MIC), biochemical study, and biotype number using MicroScan Walk-Away ${ }^{\circledR}$ system, on day 10 after the biofield treatment. The antimicrobial sensitivity assay showed $14.28 \%$ alteration out of twenty eight tested antimicrobials with respect to the control. The cefotetan sensitivity changed from intermediate (I) to inducible $\beta$-lactamase (IB), while piperacillin/tazobactam changed from resistant to IB in the treated LS 45 . Improved sensitivity was reported in tetracycline, i.e., from I to susceptible (S) in LS 45, while chloramphenicol and tetracycline sensitivity changed from R to I in treated LS 54 . Four-fold decrease in MIC value was reported in piperacillin/tazobactam, and two-fold decrease in cefotetan and tetracycline in the biofield treated LS 45 as compared to the control. MIC results showed an overall decreased MIC values in $12.50 \%$ tested antimicrobials such as chloramphenicol $(16 \mu \mathrm{g} / \mathrm{mL})$ and tetracycline $(8 \mu \mathrm{g} / \mathrm{mL})$ in LS 54 . The biochemical study showed an overall $45.45 \%$ negative reaction in the tested biochemical in both the treated isolates as compared to the control. A change in biotype number was reported in MDR isolates (LS 45 and LS 54), while in LS 54, altered biotype number, i.e., 04060374 as compared to the control (7770 4376), with identification of the new species as Stenotrophomonas maltophilia with brown color as special characteristic. The study findings suggest that $\mathrm{Mr}$. Trivedi's biofield energy treatment on clinical MDR isolates of $E$. aerogenes has the significant effect on altering the sensitivity of antimicrobials, decreasing the MIC values, changed biochemical reactions, and biotype number.
\end{abstract}

Keywords: Enterobacter aerogenes; Multidrug resistant; Antimicrobial susceptibility; Biofield treatment; Biochemical reactions; Biotyping

\section{Introduction}

Enterobacter is a genus of Gram-negative, rod shaped, facultative anaerobic, and non-spore forming microbes of family Enterobacteriaceae. Enterobacter aerogenes (E. aerogenes) is well known opportunistic bacteria emerged as nosocomial pathogen in intensive care unit patients [1]. E. aerogenes was initially named as Aerobacter aerogenes, which was later in 1960 included in the genus Enterobacter. Since 1990s, E. aerogenes has been increasingly reported for resistant against different antimicrobials, leads to emergence of multidrugresistant (MDR) isolates [2]. In the last 5 years, clinical isolates of this species have shown natural resistant against aminopenicillins, often showed resistance against $\beta$-lactams antibiotics. Resistance mechanisms in $\beta$-lactams mostly involve enzymatic degradation and plasmid-mediated broad spectrum $\beta$-lactamases [3]. However, membrane permeability, enzyme degradation, and p-glycoprotein efflux pump also contribute it to enhance the level of resistance against carbapenems, fluoroquinolones, quinolones, tetracycline, and chloramphenicol [4,5]. Enterobacter species are responsible for high morbidity and mortality rate in recent years due to nosocomial infections and other health care settings [6]. Due to extended resistance of Gram-negative bacteria against almost all antibiotics, early initiation of drug therapy is required, nowadays colistin, and polymyxin antibiotic have been preferred as an alternative drugs against Gramnegative pathogens $[7,8]$. Recent update on colistin antibiotic, a drug of $21^{\text {st }}$ century reports it's associated adverse effects and serious toxicity issues such as neurotoxicity and nephrotoxicity [9]. Despite several new drug discoveries of broad spectrum drugs or combination therapies, associated toxicities are still a serious complication. Recently, an alternate treatment therapy approach called biofield healing therapies or therapeutic touch is reported with effectively inhibiting the growth of bacterial cultures [10].

The biofield is a cumulative outcome of measurable electric and magnetic field, exerted by the human body [11]. It generates through some internal processes in the human body such as blood flow, lymph flow, brain functions, and heart function. The energy mainly exists in different forms such as potential, kinetic, magnetic, electrical, and nuclear energy produced from different sources. The energy field that surrounds and penetrates the human body is collectively defined as biofield and the extent of energy associated with biofield is termed as biofield energy. Biofield treatment includes energy therapies that interact with patient's biofield and lead to improve people's health and wellbeing. Mr. Trivedi's possesses unique biofield energy, which has been experimentally studied in various research fields. Mr. Trivedi's unique biofield treatment is also known as The Trivedi Effect ${ }^{\circ}$. Recently, Mr. Trivedi's biofield has made significant breakthrough and results

*Corresponding author: Dr. Snehasis Jana, Trivedi Science Research Laboratory Pvt. Ltd., Hall-A, Chinar Mega Mall, Chinar Fortune City, Hoshangabad Rd., Bhopal- 462026, Madhya Pradesh, India, Tel: +91-755-6660006; E-mail: publication@trivedisrl.com

Received August 31, 2015; Accepted September 29, 2015; Published October 06, 2015

Citation: Trivedi MK, Branton A, Trivedi D, Shettigar H, Nayak G, et al. (2015) Assessment of Antibiogram of Multidrug-Resistant Isolates of Enterobacter aerogenes after Biofield Energy Treatment. J Pharma Care Health Sys 2: 145. doi:10.4172/2376-0419.1000145

Copyright: @ 2015 Trivedi MK, et al. This is an open-access article distributed under the terms of the Creative Commons Attribution License, which permits unrestricted use, distribution, and reproduction in any medium, provided the original author and source are credited. 
Citation: Trivedi MK, Branton A, Trivedi D, Shettigar H, Nayak G, et al. (2015) Assessment of Antibiogram of Multidrug-Resistant Isolates of Enterobacter aerogenes after Biofield Energy Treatment. J Pharma Care Health Sys 2: 145. doi:10.4172/2376-0419.1000145

Page 2 of 5

in living organisms and nonliving materials in a different manner. In life sciences, biofield treatment has altered the antimicrobial sensitivity pattern of pathogenic microbes. In some bacteria, genus as well as species was found to be altered [12-14]. Mr. Trivedi's biofield treatment has also well scientifically studied in different areas such as materials science research [15-18], biotechnology research [19,20], and agriculture research [21-23]. Due to paucity of information and considering biofield energy as an alternate treatment approach, the present work was undertaken to evaluate the impact of Mr. Trivedi's biofield energy treatment on antimicrobials susceptibility, biochemical reactions pattern, and biotype of MDR isolates of E. aerogenes.

\section{Materials and Methods}

The Two clinical MDR lab isolates (LSs) of E. aerogenes (i.e., LS 45 and LS 54) were procured from stored stock cultures in microbiology lab, Hinduja hospital, Mumbai and stored as per suggested storage conditions until further use. The acceptability of the identification media and antimicrobial agents were checked prior to the study. The antimicrobials and biochemicals used in the study were procured from Sigma Aldrich, MA, USA. The antimicrobial susceptibility, biochemical reactions, and biotype number were evaluated on MicroScan WalkAway (Dade Behring Inc., West Sacramento, CA) using Negative Breakpoint Combo 30 (NBPC 30) panel. The panels were allowed to equilibrate to room temperature prior to rehydration. All opened panels were used in same day.

\section{Inoculum preparation}

The turbidity standard technique using direct inoculation of E. aerogenes was used. Using a sterile wooden applicator stick or bacteriological loop, the surface of 4-5 large or 5-10 small morphologically similar culture was touched for well-isolated colonies from an 18-24 hour non-inhibitory agar plate. Further, colonies were emulsified in $3 \mathrm{~mL}$ of inoculum water (autoclaved deionized water) to an equivalent of a $0.5 \mathrm{McF}$ arland barium sulfate turbidity standard. 100 $\mu \mathrm{L}$ of the standardized suspension was pipetted into $25 \mathrm{~mL}$ of inoculum water using pluronic and inverted 8-10 times.

\section{Biofield treatment}

Treated group of E. aerogenes was subjected to biofield treatment, keeping the control group untreated. The treatment group in sealed pack was handed over to Mr. Trivedi for biofield treatment under laboratory condition. Mr. Trivedi provided the treatment through his energy transmission process to the treated groups without touching the samples. Treated samples were assessed for antimicrobial sensitivity, biochemical reactions, and biotyping as per experimental design. Whilst handing over these cultures to Mr. Trivedi for treatment purposes, optimum precautions were taken to avoid contamination.

\section{Evaluation of antimicrobial susceptibility assay}

Antimicrobial susceptibility pattern of MDR E. aerogenes clinical isolates were studied using MicroScan Walk-Away using NBPC 30 panel as per manufacturer's instructions. The antimicrobial susceptibility pattern (S: Susceptible, I: Intermediate, R: Resistant, and IB: Inducible $\beta$-lactamase) and minimum inhibitory concentration (MIC) values were determined by observing the lowest antimicrobial concentration showing growth inhibition [24]. Antimicrobials used in susceptibility and MIC assay viz. amikacin, amoxicillin/K-clavulanate, ampicillin/ sulbactam, ampicillin, aztreonam, cefazolin, cefepime, cefotaxime, cefotetan, cefoxitin, ceftazidime, ceftriaxone, cefuroxime, cephalothin, chloramphenicol, ciprofloxacin, gatifloxacin, gentamicin, imipenem, levofloxacin, meropenem, moxifloxacin, norfloxacin, nitrofurantoin piperacillin, piperacillin/tazobactam, tetracycline, ticarcillin/Kclavulanate, tobramycin, and trimethoprim/sulfamethoxazole.

\section{Biochemical reaction study}

Biochemical reactions of MDR isolates of $E$. aerogenes were determined by using MicroScan Walk-Away system in both control and treated groups. Biochemicals used in the study viz. acetamide, adonitol, arabinose, arginine, cetrimide, cephalothin, citrate, colistin, esculin hydrolysis, nitrofurantoin, glucose, hydrogen sulfide, indole, inositol, kanamycin, lysine, malonate, melibiose, nitrate, oxidationfermentation, galactosidase, ornithine, oxidase, penicillin, raffinose, rhamnose, sorbitol, sucrose, tartrate, tryptophan deaminase, tobramycin, urea, and Voges-Proskauer [24].

\section{Identification by biotype number}

The biotype number of MDR isolates of E. aerogenes control and treated sample were determined by MicroScan Walk-Away processed panel data report with the help of biochemical reaction data [24].

\section{Results}

\section{Antimicrobial susceptibility study}

The antimicrobial susceptibility of control and treated MDR isolates of E. aerogenes are presented in Table 1. Biofield treatment in LS 45, showed altered sensitivity in three antimicrobials, i.e., cefotetan changed from I $\rightarrow$ IB, piperacillin/tazobactam sensitivity changed from $\mathrm{R} \rightarrow \mathrm{IB}$, and tetracycline sensitivity changed from $\mathrm{I} \rightarrow \mathrm{S}$. After biofield treatment, sensitivity of chloramphenicol and tetracycline were improved from $\mathrm{R} \rightarrow \mathrm{I}$ in LS 54 . Biofield treatment on LS 45 showed $10.71 \%$, while LS 54 showed $7.14 \%$ alterations among tested antimicrobials as compared to control (Figure 1). Overall, $14.28 \%$ antibiotics out of twenty-eight tested antimicrobials showed alteration in antimicrobial sensitivity assay with respect to control. Rest of the antimicrobials did not show any change in sensitivity pattern in clinical isolates as compared to their respective control.

\section{Determination of minimum inhibitory concentration (MIC)}

MIC values of all antimicrobials in control and biofield treated clinical MDR isolates of $E$. aerogenes are summarized in Table 2. Biofield treatment in LS 45, significantly reduced the MIC values of cefotetan, piperacillin/tazobactam, and tetracycline antimicrobials as compared to control. Chloramphenicol $(16 \mu \mathrm{g} / \mathrm{mL})$ and tetracycline $(8 \mu \mathrm{g} / \mathrm{mL})$ also showed decreased MIC values in LS 54 with respect to control. Four-fold decrease was observed in piperacillin/tazobactam $(\leq$ $16 \mu \mathrm{g} / \mathrm{mL})$ and two-fold decreases were found in cefotetan $(\leq 16 \mu \mathrm{g} /$ $\mathrm{mL}$ ) and tetracycline $(\leq 4 \mu \mathrm{g} / \mathrm{mL})$. Biofield treatment showed alteration in three antimicrobials MIC value in LS $45(9.37 \%)$, while MIC of two antimicrobials showed alteration in LS $54(6.25 \%)$ with respect to control (Figure 1). An overall $12.50 \%$ among tested antimicrobials out of thirty two showed alteration in MIC values. Rest of the antimicrobials did not show any alteration in MIC values after biofield treatment in both clinical isolates of $E$. aerogenes.

\section{Biochemical and biotype number study}

Biochemical study results of control and biofield treated isolates of $E$. aerogenes are summarized in Table 3. Results showed an overall $45.45 \%$ reverse reactions in tested biochemical as compared to control. LS 45 showed only $3.03 \%$ alteration, i.e., negative reaction (positive ' + ' to negative '-') in arginine, while in LS 54, showed $42.42 \%$ negative reaction after biofield treatment as compared to control (Figure 1). 
Citation: Trivedi MK, Branton A, Trivedi D, Shettigar H, Nayak G, et al. (2015) Assessment of Antibiogram of Multidrug-Resistant Isolates of Enterobacter aerogenes after Biofield Energy Treatment. J Pharma Care Health Sys 2: 145. doi:10.4172/2376-0419.1000145

Page 3 of 5

\begin{tabular}{|c|c|c|c|c|c|}
\hline \multirow{2}{*}{ S. No. } & \multirow{2}{*}{ Antimicrobial } & \multicolumn{2}{|c|}{ LS 45} & \multicolumn{2}{|c|}{ LS 54} \\
\hline & & C & $\mathrm{T}$ & C & $\mathrm{T}$ \\
\hline 1 & Amikacin & $\mathrm{R}$ & $\mathrm{R}$ & $\mathrm{R}$ & $\mathrm{R}$ \\
\hline 2 & Amoxicillin/k-clavulanate & $\mathrm{R}$ & $\mathrm{R}$ & $\mathrm{R}$ & - \\
\hline 3 & Ampicillin/sulbactam & $\mathrm{R}$ & $\mathrm{R}$ & $\mathrm{R}$ & - \\
\hline 4 & Ampicillin & $\mathrm{R}$ & $\mathrm{R}$ & $\mathrm{R}$ & - \\
\hline 5 & Aztreonam & $\mathrm{R}$ & $\mathrm{R}$ & $\mathrm{R}$ & $\mathrm{R}$ \\
\hline 6 & Cefazolin & $\mathrm{R}$ & $\mathrm{R}$ & $\mathrm{R}$ & - \\
\hline 7 & Cefepime & $\mathrm{R}$ & $\mathrm{R}$ & $\mathrm{R}$ & $\mathrm{R}$ \\
\hline 8 & Cefotaxime & $\mathrm{R}$ & $\mathrm{R}$ & $\mathrm{R}$ & $\mathrm{R}$ \\
\hline 9 & Cefotetan & I & IB & $\mathrm{R}$ & - \\
\hline 10 & Cefoxitin & $\mathrm{R}$ & $\mathrm{R}$ & $\mathrm{R}$ & - \\
\hline 11 & Ceftazidime & $\mathrm{R}$ & $\mathrm{R}$ & $\mathrm{R}$ & $\mathrm{R}$ \\
\hline 12 & Ceftriaxone & $\mathrm{R}$ & $\mathrm{R}$ & $\mathrm{R}$ & $\mathrm{R}$ \\
\hline 13 & Cefuroxime & $\mathrm{R}$ & $\mathrm{R}$ & $\mathrm{R}$ & - \\
\hline 14 & Cephalothin & $\mathrm{R}$ & $\mathrm{R}$ & $\mathrm{R}$ & - \\
\hline 15 & Chloramphenicol & 1 & I & $\mathrm{R}$ & 1 \\
\hline 16 & Ciprofloxacin & $\mathrm{R}$ & $\mathrm{R}$ & $\mathrm{R}$ & $\mathrm{R}$ \\
\hline 17 & Gatifloxacin & I & 1 & $\mathrm{R}$ & - \\
\hline 18 & Gentamicin & $\mathrm{R}$ & $\mathrm{R}$ & $\mathrm{R}$ & $\mathrm{R}$ \\
\hline 19 & Imipenem & $\mathrm{s}$ & $\mathrm{s}$ & $\mathrm{R}$ & $\mathrm{R}$ \\
\hline 20 & Levofloxacin & $\mathrm{R}$ & $\mathrm{R}$ & $\mathrm{R}$ & $\mathrm{R}$ \\
\hline 21 & Meropenem & S & S & $\mathrm{R}$ & $\mathrm{R}$ \\
\hline 22 & Moxifloxacin & $\mathrm{R}$ & $\mathrm{R}$ & $\mathrm{R}$ & - \\
\hline 23 & Piperacillin & $\mathrm{R}$ & $\mathrm{R}$ & $\mathrm{R}$ & - \\
\hline 24 & Piperacillin/tazobactam & $\mathrm{R}$ & IB & $\mathrm{R}$ & - \\
\hline 25 & Tetracycline & 1 & $\mathrm{~s}$ & $\mathrm{R}$ & 1 \\
\hline 26 & Ticarcillin/k-clavulanate & $\mathrm{R}$ & $\mathrm{R}$ & $\mathrm{R}$ & $\mathrm{R}$ \\
\hline 27 & Tobramycin & $\mathrm{R}$ & $\mathrm{R}$ & $\mathrm{R}$ & $\mathrm{R}$ \\
\hline 28 & $\begin{array}{l}\text { Trimethoprim/ } \\
\text { sulfamethoxazole }\end{array}$ & $\mathrm{R}$ & $\mathrm{R}$ & $\mathrm{R}$ & $\mathrm{R}$ \\
\hline
\end{tabular}

C: Control; T: Treatment; LS: Lab Isolate; S: Susceptible; I: Intermediate; R: Resistant;

IB: Inducible $\beta$-lactamase; -: Not reported

Table 1: Effect of biofield treatment on Enterobacter aerogenes to antimicrobial susceptibility.

Enterobacter aerogenes-Antibiogram

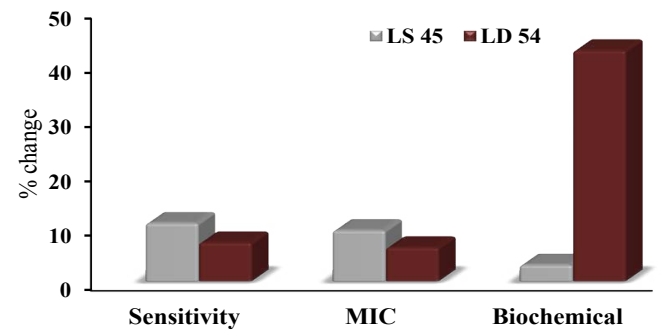

Figure 1: Antibiogram of control and biofield treated multidrug-resistant isolates of Enterobacter aerogenes.

Adonitol, arabinose, esculin hydrolysis, glucose, inositol, melibiose, oxidation-fermentation, galactosidase, raffinose, rhamnose, sorbitol, sucrose, tartrate, and Voges-Proskauer showed negative reaction after biofield treatment in LS 54. Rest of the biochemicals did not show any change in reaction with respect to the control.

Based on the above results of biochemical reactions, significant alteration in biotype number was observed in both isolates after biofield treatment as compared to control. In LS 45, changed biotype was found as 7774 5372, as compared to control biotype number 7774 7372. New organism was identified as Stenotrophomonas maltophilia with brown

color as special characteristics along with altered biotype number 0406 0374 after biofield treatment in LS 54 on day 10 with respect to control, 77704376 (Table 4).

\section{Discussion}

Biofield treatment was reported as an alternative therapy in medical health care practice [25]. This experimental was designed to demonstrate the influence of biofield treatment on MDR isolates of E. aerogenes for its susceptibility pattern, biochemical reaction and biotype number. The emergence of MDR isolates of $E$. aerogenes harbored a global health problem and an emerging Gram-negative MDROs commonly associated with severe systemic and hospital acquired infections in human. MDR is an unavoidable natural phenomenon which results due to continuous discovery of newer drugs. This experiment showed that, biofield treatment induces changes in susceptibility pattern of antimicrobials such as chloramphenicol, tetracycline, cefotetan, piperacillin/tazobactam, and tetracycline as compared to control. Tetracycline and chloramphenicol showed increased sensitivity after biofield treatment in LS 54 as compared to control. Clinical isolates of E. aerogenes have a broad ability to develop antimicrobial resistance

\begin{tabular}{|c|c|c|c|c|c|}
\hline \multirow{2}{*}{ S. No. } & \multirow{2}{*}{ Antimicrobial } & \multicolumn{2}{|c|}{ LS 45} & \multicolumn{2}{|c|}{ LS 54} \\
\hline & & $\mathrm{C}$ & $\mathrm{T}$ & C & $\mathrm{T}$ \\
\hline 1. & Amikacin & $>32$ & $>32$ & $>32$ & $>32$ \\
\hline 2. & Amoxicillin/k-clavulanate & $>16 / 8$ & $>16 / 8$ & $>16 / 8$ & $>16 / 8$ \\
\hline 3. & Ampicillin/sulbactam & $>16 / 8$ & $>16 / 8$ & $>16 / 8$ & $>16 / 8$ \\
\hline 4. & Ampicillin & $>16$ & $>16$ & $>16$ & $>16$ \\
\hline 5. & Aztreonam & $>16$ & $>16$ & $>16$ & $>16$ \\
\hline 6. & Cefazolin & $>16$ & $>16$ & $>16$ & $>16$ \\
\hline 7. & Cefepime & $>16$ & $>16$ & $>16$ & $>16$ \\
\hline 8. & Cefotaxime & $>32$ & $>32$ & $>32$ & $>32$ \\
\hline 9. & Cefotetan & 32 & $\leq 16$ & $>32$ & $>32$ \\
\hline 10. & Cefoxitin & $>16$ & $>16$ & $>16$ & $>16$ \\
\hline 11. & Ceftazidime & $>16$ & $>16$ & $>16$ & $>16$ \\
\hline 12. & Ceftriaxone & $>32$ & $>32$ & $>32$ & $>32$ \\
\hline 13. & Cefuroxime & $>16$ & $>16$ & $>16$ & $>16$ \\
\hline 14. & Cephalothin & $>16$ & $>16$ & $>16$ & $>16$ \\
\hline 15. & Chloramphenicol & 16 & 16 & $>16$ & 16 \\
\hline 16. & Ciprofloxacin & $>2$ & $>2$ & $>2$ & $>2$ \\
\hline 17. & ESBL-a Scrn & $>4$ & $>4$ & $>4$ & $>4$ \\
\hline 18. & ESBL-b Scrn & $>1$ & $>1$ & $>1$ & $>1$ \\
\hline 19. & Gatifloxacin & 4 & 4 & $>4$ & $>4$ \\
\hline 20. & Gentamicin & $>8$ & $>8$ & $>8$ & $>8$ \\
\hline 21. & Imipenem & $\leq 4$ & $\leq 4$ & $>8$ & $>8$ \\
\hline 22. & Levofloxacin & $>4$ & $>4$ & $>4$ & $>4$ \\
\hline 23. & Meropenem & $\leq 4$ & $\leq 4$ & $>8$ & $>8$ \\
\hline 24. & Moxifloxacin & $>4$ & $>4$ & $>4$ & $>4$ \\
\hline 25. & Nitrofurantoin & $>64$ & $>64$ & $>64$ & $>64$ \\
\hline 26. & Norfloxacin & $>8$ & $>8$ & $>8$ & $>8$ \\
\hline 27. & Piperacillin & $>64$ & $>64$ & $>64$ & - \\
\hline 28. & Piperacillin/tazobactam & $>64$ & $\leq 16$ & $>64$ & - \\
\hline 29. & Tetracycline & 8 & $\leq 4$ & $>8$ & 8 \\
\hline 30. & Ticarcillin/k-clavulanate & $>64$ & $>64$ & $>64$ & $>64$ \\
\hline 31. & Tobramycin & $>8$ & $>8$ & $>8$ & $>8$ \\
\hline 32. & Trimethoprim/sulfamethoxazole & $>2 / 38$ & $>2 / 38$ & $>2 / 38$ & $>2 / 38$ \\
\hline
\end{tabular}

MIC values are presented in $\mu \mathrm{g} / \mathrm{mL}$; -: Not Reported; ESBL-a, b Scrn: ExtendedSpectrum $\beta$ - Lactamase screen

Table 2: Effect of biofield treatment on Enterobacter aerogenes to MIC value of tested antimicrobials. 


\begin{tabular}{|c|c|c|c|c|c|c|}
\hline \multirow{2}{*}{ S. No. } & \multirow{2}{*}{ Code } & \multirow{2}{*}{ Biochemical } & \multicolumn{2}{|c|}{ LS 45} & \multicolumn{2}{|c|}{ LS 54} \\
\hline & & & C & $\mathrm{T}$ & C & $\mathrm{T}$ \\
\hline 1. & ACE & Acetamide & - & - & - & - \\
\hline 2. & ADO & Adonitol & + & + & + & - \\
\hline 3. & ARA & Arabinose & + & + & + & - \\
\hline 4. & ARG & Arginine & + & - & - & - \\
\hline 5. & CET & Cetrimide & + & + & - & - \\
\hline 6. & CF8 & Cephalothin & + & + & + & + \\
\hline 7. & CIT & Citrate & + & + & + & + \\
\hline 8. & CL4 & Colistin & - & - & + & + \\
\hline 9. & ESC & Esculin hydrolysis & + & + & + & - \\
\hline 10. & FD64 & Nitrofurantoin & + & + & + & + \\
\hline 11. & GLU & Glucose & + & + & + & - \\
\hline 12. & $\mathrm{H} 2 \mathrm{~S}$ & Hydrogen sulfide & - & - & - & - \\
\hline 13. & IND & Indole & - & - & - & - \\
\hline 14. & INO & Inositol & + & + & + & - \\
\hline 15. & K4 & Kanamycin & + & + & + & + \\
\hline 16. & LYS & Lysine & + & + & + & + \\
\hline 17. & MAL & Malonate & + & + & + & + \\
\hline 18. & MEL & Melibiose & + & + & + & - \\
\hline 19. & NIT & Nitrate & + & + & + & + \\
\hline 20. & OF/G & Oxidation-fermentation & + & + & + & - \\
\hline 21. & ONPG & Galactosidase & + & + & + & - \\
\hline 22. & ORN & Ornithine & + & + & - & - \\
\hline 23. & OXI & Oxidase & - & - & - & - \\
\hline 24. & P4 & Penicillin & + & + & + & + \\
\hline 25. & RAF & Raffinose & + & + & + & - \\
\hline 26. & RHA & Rhamnose & + & + & + & - \\
\hline 27. & SOR & Sorbitol & + & + & + & - \\
\hline 28. & SUC & Sucrose & + & + & + & - \\
\hline 29. & TAR & Tartrate & - & - & + & - \\
\hline 30. & TDA & Tryptophan deaminase & - & - & - & - \\
\hline 31. & TO4 & Tobramycin & + & + & + & + \\
\hline 32. & URE & Urea & + & + & - & - \\
\hline 33. & VP & Voges-Proskauer & + & + & + & - \\
\hline
\end{tabular}

C: Control; T: Treatment; LS: Lab Isolate; - (negative); + (positive)

Table 3: Effect of biofield treatment on Enterobacter aerogenes to the vital processes occurring in living organisms.

\begin{tabular}{|l|l|l|l|l|}
\hline Isolate & Group & $\begin{array}{l}\text { Biotype } \\
\text { Number }\end{array}$ & Organism Identification & Special Characteristics \\
\hline LS 45 & C & 77747372 & Enterobacter aerogenes & - \\
\hline & T & 77745372 & Enterobacter aerogenes & - \\
\hline \multirow{2}{*}{ LS 54 } & C & 77704376 & Enterobacter aerogenes & - \\
\hline T & 04060374 & $\begin{array}{l}\text { Stenotrophomonas } \\
\text { maltophilia }\end{array}$ & Brown Color \\
\hline
\end{tabular}

C: Control; T: Treatment; LS: Lab Isolate; -: Not Reported

Table 4: Effect of biofield treatment on bio typing of Enterobacter aerogenes.

[26]. Natural resistance against chloramphenicol may be mediated either enzymatically through acetylation of the drug or mechanically via active drug efflux [27]. However, efflux mechanism is generally involved to expel the antimicrobials such as tetracycline, fluoroquinolones and chloramphenicol in Enterobacter sp. [28]. Biofield treatment on clinical isolates of $E$. aerogenes might act on enzymatic level which may change the mechanism of resistant against chloramphenicol and tetracycline.

A significant decreased MIC values in cefotetan, piperacillin/ tazobactam, and tetracycline antimicrobials were found after biofield treatment in LS 45. Chloramphenicol and tetracycline also showed

decreased in MIC values in LS 54 along with increases antimicrobial sensitivity with respect to control. Increased incidence of nosocomial infections and broad resistance against third generation cephalosporins, penicillins and quinolones is a serious problem. A number of newer agents so called "fourth generation" antimicrobials remain effective for treatment $[29,30]$. Aminoglycosides, quinolones, trimethoprim/ sulphamethoxazole, and carbapenems displays good activity against Gram-negative pathogens including Enterobacter species [31,32]. Biofield treatment significantly decreased the MIC values of piperacillin/tazobactam, cefotetan, tetracycline, and chloramphenicol, which could suggest the action of biofield treatment on enzymatic/ genetic level which could affect the $\beta$-lactamases production that may lead to decrease the minimum concentration of antimicrobials required to inhibit the in vitro growth of E. aerogenes.

Several phenotypic identification tests were available to differentiate the Enterobacter species. Experimental identification of E. aerogenes was performed using a series of biochemical analysis. Basic characteristics of Enterobacter species in biochemical reactions are presence of VogesProskauer, sucrose, dextrose, glucose, lactose, rhaminose, citrate, lysine, ornithine decarboxylase, and motile in nature. Indole, methyl red and hydrogen sulphide are the negative characteristics test of Enterobacter species. Enterobacter aerogenes is a common contaminant of vegetable matter which generally forms shiny colonies with entire margins and convex elevation [33]. Biochemical reactions of control MDR isolates of $E$. aerogenes were well supported with literature data [34]. Biofield treatment showed alteration, i.e., negative reaction in arginine biochemical in LS 45 and adonitol, arabinose, esculin hydrolysis, glucose, inositol, melibiose, oxidation-fermentation, galactosidase, raffinose, rhamnose, sorbitol, sucrose, tartrate and Voges-Proskauer in LS 54 as compared to control, which is the basic character of Enterobacter species. Various biochemical mechanisms are involved in biochemical, such as enzymatic alteration involved in sugar transferase, isomerization of biochemical, hydrolyzing reactions, etc. [35]. Biofield treatment on MDR isolates of E. aerogenes may alter the enzymatic biochemical reactions which could show result in altered biochemical reactions as compared to control.

Biotyping was also performed using an automated system and found a significant changed in biotype number in both isolates on day 10, and a new organism was identified as Stenotrophomonas maltophilia after biofield treatment in LS 54 as compared to control. The results of biotype number and identification of new species are based on the biochemical reaction pattern of control and treated samples. The biochemical reaction patterns of LS 54 after biofield treatment are well supported with literature data [36], which suggest the alteration in species as Stenotrophomonas maltophilia (Table 4). Based on this, biochemical reaction pattern, biotype number and identified species results are well collaborated.

In biomedical health care system, biofield therapies are very popularly used to enhance human wellbeing and helps in minimizing patient's health [25]. Biofield treatment might act as a communication system using electromagnetic frequencies which will carry message from environment to organism and vice versa [37]. However, National Center for Complementary and Alternative Medicine/National Institute of Health (NCCAM/NIH), now defined biofield therapies in subcategory of energy therapies as one of the five complementary medicine domains [25]. In microbiology, Mr. Trivedi's biofield treatment was reported on pathogenic microorganism which altered the phenotypic characteristics of microorganism [12-14]. Alteration in antimicrobials sensitivity pattern after treatment might involve cell receptor protein and its interactions at molecular level. Experimental 
Citation: Trivedi MK, Branton A, Trivedi D, Shettigar H, Nayak G, et al. (2015) Assessment of Antibiogram of Multidrug-Resistant Isolates of Enterobacter aerogenes after Biofield Energy Treatment. J Pharma Care Health Sys 2: 145. doi:10.4172/2376-0419.1000145

Page 5 of 5

data showed that, biofield treatment include significant changes in susceptibility pattern of antimicrobials, biochemical reactions, MIC values, and biotype number. Biofield treatment could be an alternative approach to study the alteration in sensitivity pattern of MDR isolates.

\section{Conclusions}

Overall data illustrate that there has a significant impact of biofield treatment on antimicrobial susceptibility pattern, MIC values, biochemical reactions, and biotype number in clinical MDR isolates of E. aerogenes. Antimicrobial sensitivity assay showed $14.28 \%$ alteration, MIC values were significantly decreased, i.e., $12.50 \%$ among tested antimicrobials. Biochemical study showed an overall $45.45 \%$ altered reactions in tested biochemical as compared to control after biofield treatment in clinical isolates. On the basis of changed biotype number (0406 0374), new organism was identified as Stenotrophomonas maltophilia with brown color as special characteristics after biofield treatment in LS 54 as compared to control (7770 4376). Mr. Trivedi's biofield energy treatment could be applied to improve the sensitivity of antimicrobials, which may be an alternative therapeutic healing approach in medical science to fight against infections due to the emergence of multi drug-resistant strain of E. aerogenes.

\section{Acknowledgements}

Authors gratefully acknowledged the whole team of PD Hinduja National Hospital and MRC, Mumbai, Microbiology Lab for their support. Authors also would like to thanks Trivedi Science, Trivedi master wellness and Trivedi testimonials for their support during the work.

\section{References}

1. Davin-Regli A, Pages JM (2015) Enterobacter aerogenes and Enterobacter cloacae; versatile bacterial pathogens confronting antibiotic treatment. Front Microbiol 6: 392.

2. Davin-Regli A, Bolla JM, James CE, Lavigne JP, Chevalier J, et al. (2008) Membrane permeability and regulation of drug "influx and efflux" in enterobacterial pathogens. Curr Drug Targets 9: 750-759.

3. Jacoby GA (2009) AmpC beta-lactamases. Clin Microbiol Rev 22: 161-182, Table of Contents.

4. Nikaido H (2003) Molecular basis of bacterial outer membrane permeability revisited. Microbiol Mol Biol Rev 67: 593-656.

5. Pages JM, James CE, Winterhalter M (2008) The porin and the permeating antibiotic: A selective diffusion barrier in Gram-negative bacteria. Nat Rev Microbiol 6: 893-903.

6. Chang SC, Chen YC, Hsu LY (1990) [Epidemiologic study of pathogens causing nosocomial infections]. J Formos Med Assoc 89: 1023-1030, 1015.

7. Stein A, Raoult D (2002) Colistin: an antimicrobial for the 21st century? Clin Infect Dis 35: 901-902.

8. Markou N, Apostolakos H, Koumoudiou C, Athanasiou M, Koutsoukou A, et al (2003) Intravenous colistin in the treatment of sepsis from multiresistant Gramnegative bacilli in critically ill patients. Crit Care 7: R78-83.

9. Biswas S, Brunel JM, Dubus JC, Reynaud-Gaubert M, Rolain JM (2012) Colistin: An update on the antibiotic of the 21st century. Expert Rev Anti Infect Ther 10: 917-934.

10. Lucchetti G, de Oliveira RF, Gonçalves JP, Ueda SM, Mimica LM, et al. (2013) Effect of Spiritist "passe" (Spiritual healing) on growth of bacterial cultures. Complement Ther Med 21: 627-632.

11. Movaffaghi Z, Farsi M (2009) Biofield therapies: biophysical basis and biological regulations? Complement Ther Clin Pract 15: 35-37.

12. Trivedi MK, Patil S, Shettigar H, Gangwar M, Jana S (2015) Antimicrobial sensitivity pattern of Pseudomonas fluorescens after biofield treatment. J Infect Dis Ther 3: 222.

13. Trivedi MK, Patil S, Shettigar H, Bairwa K, Jana S (2015) Phenotypic and biotypic characterization of Klebsiella oxytoca: An impact of biofield treatment. J Microb Biochem Technol 7: 203-206.
14. Trivedi MK, Patil S, Shettigar H, Bairwa K, Jana S (2015) Effect of biofield treatment on phenotypic and genotypic characteristic of Provindencia rettgeri. Mol Biol 4: 129.

15. Trivedi MK, Nayak G, Patil S, Tallapragada RM, Latiyal O (2015) Studies of the atomic and crystalline characteristics of ceramic oxide nano powders after bio field treatment. Ind Eng Manage 4: 161

16. Trivedi MK, Patil S, Tallapragada RM (2013) Effect of biofield treatment on the physical and thermal characteristics of silicon, tin and lead powders. J Material Sci Eng 2: 125.

17. Trivedi MK, Patil S, Tallapragada RM (2013) Effect of biofield treatment on the physical and thermal characteristics of vanadium pentoxide powder. $\mathrm{J}$ Materia Sci Eng S11: 001.

18. Trivedi MK, Patil S, Tallapragada RM (2015) Effect of biofield treatment on the physical and thermal characteristics of aluminium powders. Ind Eng Manage 4: 151.

19. Patil SA, Nayak GB, Barve SS, Tembe RP, Khan RR (2012) Impact of biofield treatment on growth and anatomical characteristics of Pogostemon cablin (Benth.). Biotechnology 11: 154-162.

20. Nayak G, Altekar N (2015) Effect of biofield treatment on plant growth and adaptation. J Environ Health Sci 1: 1-9.

21. Shinde V, Sances F, Patil S, Spence A (2012) Impact of biofield treatment on growth and yield of lettuce and tomato. Aust J Basic Appl Sci 6: 100-105.

22. Sances F, Flora E, Patil S, Spence A, Shinde V (2013) Impact of biofield treatment on ginseng and organic blueberry yield. Agrivita J Agric Sci 35: 22-29.

23. Lenssen AW (2013) Biofield and fungicide seed treatment influences on soybean productivity, seed quality and weed community. Agricultural Journal 8. $138-143$.

24. Fader RC, Weaver E, Fossett R, Toyras M, Vanderlaan J, et al. (2013) Multilaboratory study of the biomic automated well-reading instrument versus MicroScan WalkAway for reading MicroScan antimicrobial susceptibility and identification panels. J Clin Microbiol 51: 1548-1554.

25. Clarke TC, Black LI, Stussman BJ, Barnes PM, Nahin RL (2015) Trends in the use of complementary health approaches among adults: Unites States, 2002 2012. National health statistics reports; no 79. Hyattsville, MD: National Center for Health Statistics.

26. Miró E, Alonso C, Navarro F, Mirelis B, Prats G (1995) [Resistencia alimipenemen Enterobacter aerogenes]. Enferm Infecc Microbiol Clin 13: 278-282.

27. Ghisalberti D, Masi M, Pagès JM, Chevalier J (2005) Chloramphenicol and expression of multidrug efflux pump in Enterobacter aerogenes. Biochem Biophys Res Commun 328: 1113-1118.

28. Mallea M, Chevalier J, Bornet CE, Eyraud A, Davin-Regli A, et al. (1998) Porin alteration and active efflux: Two in vivo drug resistance strategies used by Enterobacter aerogenes. Microbiology 144: 3003-3009.

29. Chow JW, Fine MJ, Shlaes DM, Quinn JP, Hooper DC, et al. (1991) Enterobacter bacteremia: Clinical features and emergence of antibiotic resistance during therapy. Ann Intern Med 115: 585-590.

30. Segreti J, Levin S (1996) Bacteriologic and clinical applications of a new extended-spectrum parenteral cephalosporin. Am J Med 100: 45S-51S.

31. Norrby SR (1995) Carbapenems. Med Clin North Am 79: 745-759.

32. Jones RN (2001) Resistance patterns among nosocomial pathogens: Trends over the past few years. Chest 119: 397S-404S.

33. Zabransky RJ, Hall JW, Day FE, Needham GM (1969) Klebsiella, Enterobacter, and Serratia: Biochemical differentiation and susceptibility to ampicillin and three cephalosporin derivatives. Appl Microbiol 18: 198-203.

34. MacFaddin JF (1980) Biochemical tests for identification of medical bacteria ( $2^{\text {nd }}$ edn), Williams and Wilkins, Baltimore.

35. Schramm VL (2011) Chemical mechanisms in biochemical reactions. J Am Chem Soc 133: 13207-13212.

36. Denton M, Kerr KG (1998) Microbiological and clinical aspects of infection associated with Stenotrophomonas maltophilia. Clin Microbiol Rev 11: 57-80.

37. Warber SL, Gordon A, Gillespie BW, Olson M, Assefi N (2003) Standards for conducting clinical biofield energy healing research. Altern Ther Health Med 9: A54-A64. 